\title{
ANALISIS LERENG TERASERING DALAM UPAYA PENANGGULANGAN LONGSOR METODE FELLENIUS DENGAN PROGRAM GEOSTUDIO SLOPE
}

\author{
Dimas Haryadi ${ }^{1)}$, Mawardi ${ }^{2)}$, Makmun R. Razali ${ }^{3)}$ \\ ${ }^{122) 3)}$ Program Studi Teknik Sipil, Fakultas Teknik UNIB, Jl. W. R. Supratman, \\ Kandang Limun, Bengkulu 38371, Telp. (0736)344087 \\ e-mail: mawardi001@gmail.com
}

\begin{abstract}
Abstrak
Kawasan Pembangkit Listrik Tenaga Air (PLTA) Musi Kabupaten Kepahiang merupakan kawasan perbukitan yang memiliki lereng-lereng curam yang rawan terhadap kelongsoran. Salah satu peristiwa longsor terjadi pada awal bulan Oktober 2017 tepatnya terjadi di jalan lintas antara Desa Susup Kabupaten Bengkulu Tengah dan Kecamatan Ujan Mas Kabupaten Kepahiang. Penelitian ini bertujuan untuk menganalisisa stabilitas lereng terasering dengan menggunakan Metode Fellenius. Hasil pengujian sifat fisis tanah menunjukan bahwa tanah pada lereng dikawasan PLTA Musi Kepahiang adalah tanah lempung. Lereng yang diteliti di kawasan PLTA Musi semuanya rawan terhadap kelongsor karena faktor keamanan, FK < 1,5. Berdasarkan hasil penelitian pada lereng 1 tipe lereng yang paling aman nilai faktor keamanan adalah tipe lereng terasering trap 3 kemiringan $19^{\circ}, \mathrm{FK}=1,61$ lebih besar dari nilai faktor keamanan tipe lereng terasering trap 2 kemiringan $19^{\circ}, \mathrm{FK}=1,57$ dan nilai faktor keamanan tipe lereng aman kemiringan $19^{\circ}$, $\mathrm{FK}=1,519$ serta nilai faktor keamanan tipe lereng asli kemiringan $30^{\circ}$, $\mathrm{FK}=0,88$.
\end{abstract}

Kata kunci: metode fellenius, faktor keamanan lereng (FK), terasering

\begin{abstract}
The Musi Hydroelectric Power Plant area in Kepahiang Regency is a hilly area that has steep slopes that are prone to landslides. One of the landslides that occurred at October 2017 precisely occurred on a highway between Susup Village, Bengkulu Tengah Regency and Ujan Mas District, Kepahiang Regency. This study aims to analyze the slope stability of the terraces using the Fellenius Method. The results of testing the physical properties of the soil indicate that the soil on the slopes of the area of the Musi Hydroelectric Power Plant is clay. The slopes studied in the Musi hydropower area are all prone to landslides because safety factor, $F K<1,5$. Based on the results of the research on the slopes of the safest type 1 slope the value of the safety factor is the type of slope of the slope trap 3, 19 $, F K=1,61$ greater than the safety factor value of slope type 2 slope trap $19^{\circ}, F K=1,57$ and safe slope type safety factor value slope of $19^{\circ}, F K=1.519$ and the value of the safety factor of the original slope type of slope $30^{\circ}, F K=$ 0,88 .
\end{abstract}

Keywords: fellenius method, safe factor (SF), terraces 


\section{PENDAHULUAN}

Permukaan tanah mempunyai topografi yang berbeda sehingga membentuk suatu lereng (slope). Lereng merupakan bagian dari topografi permukaan tanah yang memiliki sudut kemiringan tertentu. Lereng dapat saja terjadi secara alami ataupun buatan, lereng yang terbentuk secara alami misalnya lereng perbukitan dan tebing-tebing sungai, sedangkan lereng buatan dapat berupa bendung, tanggul sungai dan tambang terbuka. Salah satu akibat dari perbedaan sudut kemiringan tersebut dapat mempengaruhi kestabilan lereng tersebut. Kestabilan lereng erat kaitanya dengan kelongsoran atau pergerakan tanah yang merupakan proses perpindahan massa tanah secara alami dari tempat yang tinggi ke tempat yang rendah.

Provinsi Bengkulu merupakan daerah yang memiliki topografi beragam karena sebagian besar merupakan daerah Bukit Barisan, sehingga membuat wilayah Provinsi Bengkulu memiliki lereng-lereng curam yang rawan terhadap bencana tanah longsor. Salah satunya peristiwa longsor terjadi pada awal bulan Oktober 2017 tepatnya terjadi di jalan lintas antara Desa Susup Kabupaten Bengkulu Tengah dan Kecamatan Ujan Mas Kabupaten Kepahiang yang merupakan Kawasan PLTA (Pembangkit Listrik Tenaga Air) Musi Kabupaten Kepahiang. Peristiwa tersebut memutuskan akses jalur transportasi antara dua kabupaten tersebut.

Untuk meminimalisir terjadinya kelongsoran pada lereng perlu adanya tindakan pencegahan, banyak cara dapat dilakukan untuk mencegah terjadinya longsor, seperti membuat terasering pada lereng. Dengan dibuat demikian maka akan mengurangi sudut kemiringan lereng. Setelah itu dilakukan perhitungan stabilitas lereng guna memeriksa keamanan dari lereng tersebut.

\section{Tanah}

Tanah didefinisikan sebagai material yang terdiri dari butiran mineral-mineral padat yang tidak terikat secara kimia satu sama lain dan dari bahan-bahan organik yang telah melapuk (yang berpartikel padat) disertai dengan zat cair dan gas yang mengisi ruang-ruang kosong di antara partikel-partikel padat tersebut (Das, 1994).

\section{Lereng}

Lereng merupakan bagian dari topografi permukaan tanah yang memiliki sudut kemiringan tertentu. Lereng dapat saja terjadi secara alami ataupun buatan, lereng yang terbentuk secara alami misalnya lereng perbukitan dan tebing-tebing sungai, sedangkan lereng buatan dapat berupa bendung, tanggul sungai dan tambang terbuka.

\section{Longsoran}

Longsoran atau pergerakan tanah merupakan proses perpindahan massa tanah secara alami dari tempat yang tinggi ke tempat yang rendah. Definisi diatas dapat menunjukkan bahwa pergerakan massa yang bergerak dapat berupa massa tanah, massa batuan ataupun kombinasi keduanya. Kelongsoran pada lereng alami atau lereng buatan dapat terjadi secara perlahan atau tiba-tiba, pergerakan tanah ini biasanya diakibatkan oleh adanya pemicu kelongsoran.Salah satu pemicu kelongsoran lereng adalah penurunan kuat geser tanah (c) dan sudut geser dalam ( ) yang selanjutnya menyebabkan kelongsoran.

\section{Stabilitas lereng}

Stabilitas lereng merupakan proses analisis perhitungan dan membandingkan antara tegangan geser dengan kekuatan geser dari tanah atau bidang lereng. Kekuatan geser suatu tanah merupakan daya tolak internal tanah terhadap keruntuhan atau pergeseran tanah sepanjang bidang geser (Das, 1994). Stabilitas lereng sangat dipengaruhi oleh kekuatan geser tanah untuk menentukan 
kemempuan tanah menahan keruntuhan. Jika permukaan membentuk suatu sudut kemiringan maka massa tanah atau batuan diatas bidang gelincir akan bergerak ke arah bawah akibat gravitasi. Dalam peristiwa tersebut terjadi pergerakan massa tanah pada arah ke bawah dan pada arah ke luar (Terzaghi, 1987).

Kondisi ini dapat dicegah dengan mengurangi sudut kemiringan atau memperpanjang lereng tersebut, dengan demikian gaya dorongtegangan geser tidak melampaui gaya tolak yang berasal dari kekuatan geser tanah sepanjang bidang longsor seperti yang diperlihatkan pada Gambar 1.

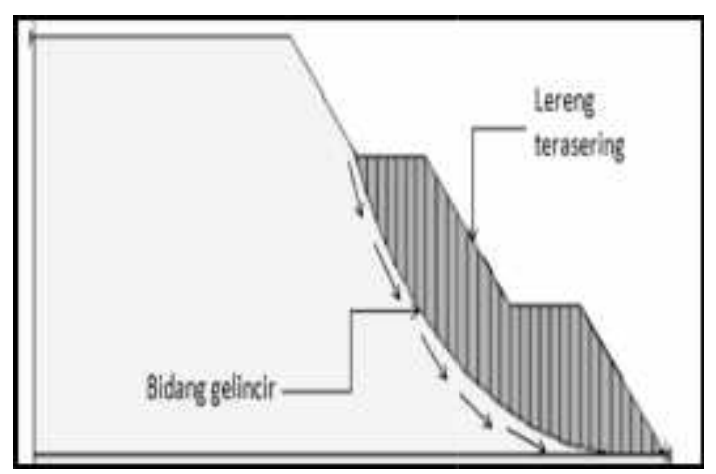

Gambar 1. Bidang Longsor Lereng Terasering

Kemampuan kekuatan geser tanah untuk menahan tekanan tanah yang mengalami keruntuhan sangat mempengaruhi stabilitas lereng. Analisis stabilitas lereng juga didasarkan pada konsep keseimbangan batas plastis (limit plastic equilibrium).

Tabel 1. Nilai dari Faktor Keamanan (FK) Berdasarkan Intensitas Kelongsoran

\begin{tabular}{|c|l|}
\hline $\begin{array}{c}\text { Nilai Faktor } \\
\text { Keamanan(FK) }\end{array}$ & Intensitas Kelongsoran \\
\hline FK $<1,5$ & $\begin{array}{l}\text { Lereng dalam keadaan } \\
\text { tidak stabil }\end{array}$ \\
FK $=1,5$ & $\begin{array}{l}\text { Lereng kemungkinan } \\
\text { dalam keadaan tidak stabil } \\
\text { Fereng dalam keadaan } \\
\text { stabil }\end{array}$ \\
\hline
\end{tabular}

Sumber : Hardiyatmo, 2002

\section{Metode Fellenius}

Metode Fellenius (Fellenius, 1936 dalam Hardiyatmo, 2002) menganggap bahwa gaya-gaya yang bekerja pada sisi kanan kiri dari sembarang irisan mempunyai resultan nol pada arah tegak lurus bidang longsor. Dengan anggapan ini, keseimbangan arah vertikal dan gaya-gaya yang bekerja dengan memperhatikan tekanan air pori.

Bentuk persamaan faktor keamanan untuk analisis stabilitas lereng cara Fellenius (Hardiyatmo, 2002), adalah:

$F K=\frac{\left.\sum c^{\prime} \cdot l+\left[p_{W}-u \cdot l\right] \text { tan } \phi^{\prime}\right]}{\sum W \sin \alpha}$

\section{Geostudio Slope/W 2012}

Geostudio Office adalah aplikasi untuk pemodelan geoteknik dan geolingkungan. Aplikasi ini melingkupi SLOPE/W, $S E E P / W, S I G M A / W, Q U A K E / W, T E M P / W$, dan CTRAN/W yang sifatnya terintegrasi sehingga memungkinkan untuk menggunakan hasil dari satu produk ke produk yang lain (Pohan, 2018).

SLOPE/W merupakan produk perangkat lunak untuk menghitung faktor keamanan lereng baik yang tersusun oleh tanah maupun batuan. Analisis faktor keamanan dapat dilakukan dalam kondisi lapangan yang berbeda seperti berbagai macam kemiringan tanah, terdapat tekanan air pori atau tidak, maupun sifat tanah yang berbedabeda (Adi, 2018).

\section{METODE PENELITIAN}

Penelitian ini menggunakan metode penelitian yang dilakukan di laboratorium mekanika tanah Universitas Bengkulu serta analisis matematika. Peneltian menggunakan sampel tanah pada 3 lereng di Kawasan PLTA (Pembangkit Listrik Tenaga Air) Musi di Kecamatan Ujan Mas, Kabupaten Kepahiang, Provinsi Bengkulu. Pengujian dilakukan untuk menghitung faktor keamanan (FK) lereng pada kondisi tanah 
asli. Pengujian atau penyelidikan tanah berfungsi untuk memperoleh data dan informasi parameter sifat fisik maupun sifat mekanika tanah, selanjutnya paremeterparameter tersebut digunakan sebagai bahan analisis dan pertimbangan dalam perencanaan dan desain tipe penanganan longsor. Berikut merupakan beberapa pengujian yang dibutuhkan untuk menganalisis stabilitas lereng:

1. Analisa Saringan (SNI 3432-2008)

2. Berat Jenis (SNI 1964-2008)

3. Berat Isi (SNI 02-3637-1994)

4. Batas-batas Konsistensi Tanah

5. Batas Cair (SNI 1967-2008)

6. Batas Plastis (SNI 1966-2008)

7. Kuat Geser Langsung (SNI 2813-2008)

\section{Skenario optimasi lereng}

Pada penelitian ini skenario optimasi lereng dilakukan dalam beberapa pengkondisian. Variasi tersebut dibagi menjadi 4 variasi yaitu:



Gambar 2. Model Skenario Optimasi

Lereng

\section{HASIL DAN PEMBAHASAN}

Sampel tanah yang diteliti berasal dari 3 lereng yang berada pada kawasan PLTA Musi Kabupaten Kepahiang, Provinsi Bengkulu. Penelitian dilaksanakan dengan mengambil sampel tanah dari lokasi, kemudian dilakukan pengukuran serta pengambilan titik koordinat menggunakan alat GPS, lereng 1 berada di koordinat $\mathrm{S} 03.56374^{\circ} \mathrm{E} 102.49768^{\circ}$, lereng 2 berada di koordinat $S$ $03.56346^{\circ}$ E $102.5018^{\circ}$ dan
Lereng 3 berada di koordinat S $03.57932^{\circ} \mathrm{E}$ 102.4916 . Pengujian sampel tanah dilakukan di Laboratorium Geologi Teknik Program Studi Teknik Sipil Universitas Bengkulu selama kurang lebih 1 minggu. Penelitian yang dilakukan meliputi uji fisis tanah dan uji mekanik tanah. Data yang diperoleh dari hasil penelitian kemudian digunakan untuk perhitungan analisis stabilitas lereng dengan menggunakan Metode Fellenius (ordinary method of slice) melalui program computer Geostudio Slope/W 2012 untuk mendapatkan nilai faktor keamanan (FK) dari 3 lereng yang diteliti tersebut.

\section{Hasil pengujian sifat fisis tanah}

Sampel tanah yang di ambil dilakukan uji fisis tanah untuk mengetahui karakteristik tanah dari 3 lereng berbeda.

\section{Berat jenis tanah}

Dari 3 lereng tersebut diketahui jenis tanah termasuk kedalam jenis tanah lempung organik karena berat jenis dari ketiga lereng berada pada nilai 2,58-2,68.

Tabel 2. Hasil Pengujian Berat Jenis

\begin{tabular}{|c|c|c|}
\hline Lereng & \multicolumn{2}{|c|}{ Berat jenis } \\
\hline $1 \mathrm{~A}$ & 2,65 & \multirow{2}{*}{2,6248} \\
\hline $1 \mathrm{~B}$ & 2,61 & \multirow{2}{*}{2,6373} \\
\hline $1 \mathrm{C}$ & 2,61 & \\
\hline $2 \mathrm{~A}$ & 2,65 & \multirow{2}{*}{2,638} \\
\hline $2 \mathrm{~B}$ & 2,64 & \multirow{2}{*}{2,658} \\
\hline $2 \mathrm{C}$ & 2,62 & \\
\hline $3 \mathrm{~A}$ & 2,68 & \\
\hline $3 \mathrm{~B}$ & 2,63 & \\
\hline $3 \mathrm{C}$ & 2,67 & \\
\hline
\end{tabular}

\section{Berat isi}

Nilai dari berat isi basah dan berat isi kering dapat dilihat pada Tabel 3. Nilai ini nantinya akan digunakan dalam perhitungan analisis stabilitas lereng dengan menggunakan Metode Fellenius. 
Tabel 3. Hasil Pengujian Berat Isi

\begin{tabular}{|c|c|c|c|c|}
\hline \multirow[b]{2}{*}{ Lereng } & \multicolumn{4}{|c|}{ Berat Isi } \\
\hline & $\begin{array}{c}\mathrm{W}_{\mathrm{b}} \\
\mathrm{gr} / \mathrm{cm}^{3}\end{array}$ & $\begin{array}{c}\mathrm{W}_{\mathrm{b}} \\
\left(\mathrm{kN} / \mathrm{cm}^{3}\right.\end{array}$ & $\begin{array}{c}\mathrm{W}_{\mathrm{d}} \\
\left(\mathrm{gr} / \mathrm{cm}^{3}\right.\end{array}$ & $\begin{array}{c}\mathrm{W}_{\mathrm{d}} \\
\left(\mathrm{kN} / \mathrm{cm}^{3}\right)\end{array}$ \\
\hline $1 \mathrm{~A}$ & 1,37 & \multirow{3}{*}{14,39} & 1,20 & \multirow{3}{*}{17,260} \\
\hline $1 \mathrm{~B}$ & 1,48 & & 1,22 & \\
\hline $1 \mathrm{C}$ & 1,54 & & 1,26 & \\
\hline $2 \mathrm{~A}$ & 1,34 & \multirow{3}{*}{14,254} & 1,08 & \multirow{3}{*}{16,439} \\
\hline $2 \mathrm{~B}$ & 1,46 & & 1,07 & \\
\hline $2 \mathrm{C}$ & 1,56 & & 1,12 & \\
\hline $3 \mathrm{~A}$ & 1,65 & \multirow{3}{*}{16,520} & 1,19 & \multirow{3}{*}{17,244} \\
\hline $3 \mathrm{~B}$ & 1,71 & & 1,24 & \\
\hline $3 \mathrm{C}$ & 1,68 & & 1,11 & \\
\hline
\end{tabular}

\section{Analisis saringan}

Berdasarkan hasil pengujian analisis saringan pada 3 lereng mendapatkan hasil presentase tanah yang lolos saringan 100 hampir setengah dari jumlah sampel yang dilakukan pengujian. Lereng 1 sebesar $46,63 \%$, lereng 2 sebesar $55,20 \%$, dan lereng 3 sebesar 52,81\%. Hasil pengujian tersebut menunjukan bahwa diameter butir tanah pada 3 lereng sangat kecil dan termasuk tanah lempung.

\section{Hasil pengujian batas-batas konsistensi}

Berdasarkan hasil penelitian batas-batas konsistensi yaitu pengujian batas plastis (plastic limit) dan batas cair (liquid limit) yang dilakukan pada 3 lereng menunjukan bahwa lereng 1, lereng 2 dan lereng 3 berada pada zona $\mathrm{OH}$ yang berarti jenis tanah pada semua lereng yang dilakukan pengujian adalah tanah lempung organik.

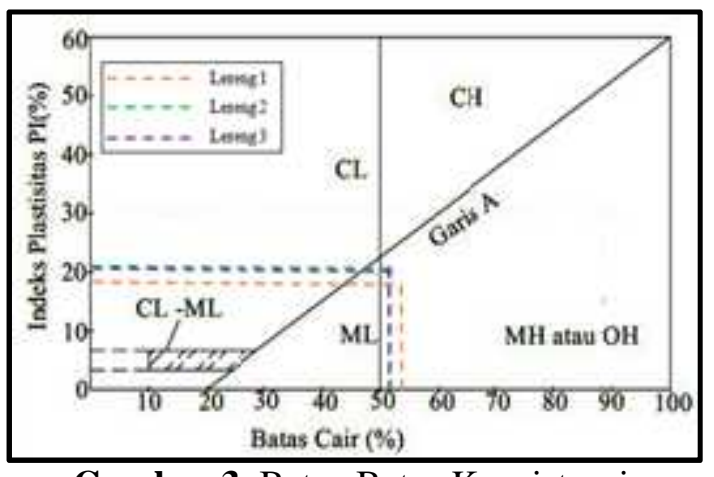

Gambar 3. Batas-Batas Konsistensi

\section{Hasil pengujian sifat mekanik tanah}

Sampel tanah yang diambil dilakukan uji mekanik tanah untuk mengetahui karakteristik tanah dari 3 lereng berbeda. Berdasarkan hasil rata-rata nilai uji mekanik tanah pada lereng 1 , lereng 2 dan lereng 3 bisa disimpulkan bahwa jenis tanah ketiga lereng tersebut merupakan tanah lempung kelanauan. Hasil tersebut dikarenakan nilai $\phi$ ' ketiga lereng lebih berada diantara $25^{\circ}$ $30^{\circ}$ yang masuk kedalam kategori lempung kelanauan.

Tabel 4. Hasil Pengujian Direct Shear

\begin{tabular}{|c|c|c|c|c|}
\hline Sampel & $\begin{array}{l}\text { Kohesi } \\
\mathrm{C}(\mathrm{kPa})\end{array}$ & $\begin{array}{l}\text { Rerata } \\
\mathrm{C}(\mathrm{kPa})\end{array}$ & \begin{tabular}{|c|} 
Sudut \\
Geser $\left(^{\circ}\right)$
\end{tabular} & $\begin{array}{c}\text { Rerata } \\
\left({ }^{\circ}\right)\end{array}$ \\
\hline $\begin{array}{c}\text { Lereng } \\
1 \mathrm{~A}\end{array}$ & 20,357 & \multirow{3}{*}{21,758} & 25,144 & \multirow{3}{*}{25,605} \\
\hline $\begin{array}{c}\text { Lereng } \\
1 \mathrm{~B}\end{array}$ & 21,973 & & 25,606 & \\
\hline $\begin{array}{c}\text { Lereng } \\
1 \mathrm{C}\end{array}$ & 22,943 & & 26,065 & \\
\hline $\begin{array}{c}\text { Lereng } \\
2 \mathrm{~A}\end{array}$ & 27,790 & \multirow{3}{*}{24,881} & 25,836 & \multirow{3}{*}{25,608} \\
\hline $\begin{array}{c}\text { Lereng } \\
\text { 2B }\end{array}$ & 24,881 & & 24,678 & \\
\hline $\begin{array}{c}\text { Lereng } \\
2 \mathrm{C}\end{array}$ & 21,973 & & 26,678 & \\
\hline $\begin{array}{c}\text { Lereng } \\
3 \mathrm{~A}\end{array}$ & 25,205 & \multirow{3}{*}{24,771} & 27,642 & \multirow{3}{*}{26,285} \\
\hline $\begin{array}{c}\text { Lereng } \\
\text { 3B }\end{array}$ & 23,266 & & 25,376 & \\
\hline $\begin{array}{c}\text { Lereng } \\
3 \mathrm{C}\end{array}$ & 25,851 & & 25,836 & \\
\hline
\end{tabular}

Hasil dari pengujian sifat fisis melalui uji berat jenis tanah, uji berat isi tanah, uji analisis saringan dan uji batas-batas konsistensi tanah ditambah dengan uji mekanik tanah melalui pengujian direct shear menunjukan bahwa lereng 1, lereng 2 danlereng 3 memiliki jenis tanah clay (lempung). Tanah lempung memiliki potensi untuk terjadi longsor jika memiliki tingkat kecuraman lereng yang tinggi dan kondisi tanah dalam keadaan jenuh. 
Perhitungan faktor aman dengan metode Fellenius

Perhitungan factor aman dilakukand engan dua cara, pertama dilakukan dengan program aplikasi Geostudio Slope/W 2012. Nilai factor aman didapat dari program Geostudio Slope/W 2012 dihitung ulang menggunakan persamaan dan dibantu dengan program Microsoft Excel sebagai bahan perbandingan. Perhitungan dilakukan pada 3 lereng, setiap masing-masing lereng dilakukan empat perhitungan pada variasi bentuk lereng, yaitu lereng dengan kemiringan asli, lereng dengan kemiringan lereng aman dan lereng dengan terasering trap 2, serta lereng dengan terasering trap 3. Perhitungan tersebut dilakukan supaya dapat mengetahui hubungan sudut geser, kohesi dan variasi bentuk lereng terhadap factor aman.

Tabel 5. Berat Isi

\begin{tabular}{|c|c|c|c|c|c|}
\hline \multicolumn{2}{|c|}{ Lereng } & \multirow{2}{*}{$\begin{array}{c}\mathbf{c}^{\prime} \\
(\text { Kpa })\end{array}$} & \multirow{2}{*}{$\begin{array}{c}\gamma_{b} \\
\left(k N / m^{3}\right)\end{array}$} & \multirow{2}{*}{$\begin{array}{c}\gamma_{\text {sat }} \\
\left(\mathbf{k N} / \mathbf{m}^{3}\right)\end{array}$} & \multirow{2}{*}{$\begin{array}{l}\phi^{\prime} \\
\left(^{\circ}\right)\end{array}$} \\
\hline & Tipe & & & & \\
\hline & KA & 1,758 & 4,390 & 7,260 & 25,605 \\
\hline & KLA & 21,758 & 14,390 & 17,260 & 25,605 \\
\hline & TT2 & 21,758 & 14,390 & 17,260 & 25,605 \\
\hline & TT3 & 21,758 & 14,390 & 17,260 & 25,605 \\
\hline & KA & 24,881 & 14,254 & 16,439 & 25,602 \\
\hline & KLA & 24,881 & 14,254 & 16,439 & 25,602 \\
\hline & TT2 & 24,881 & 14,254 & 16,439 & 25,602 \\
\hline & TT3 & 24,881 & 14,254 & 16,439 & 25,602 \\
\hline & KA & 24,774 & 16,520 & 17,244 & 26,285 \\
\hline & KLA & 24,774 & 16,520 & 17,244 & 26,285 \\
\hline & TT2 & 24,774 & 16,520 & 17,244 & 26,285 \\
\hline & TT3 & 24,774 & 16,520 & 17,244 & 26,285 \\
\hline
\end{tabular}

Tabel 6. Angka Keamanan Lereng

\begin{tabular}{|c|c|c|c|c|c|}
\hline \multirow{2}{*}{ Lereng } & \multicolumn{4}{c|}{ FK } \\
\cline { 3 - 6 } & $\begin{array}{c}\text { Sudut } \\
\text { Lereng }\end{array}$ & Air Pori & $\begin{array}{c}\text { Sudut } \\
\text { Lereng }\end{array}$ & $\begin{array}{c}\text { Tanpa } \\
\text { Air Pori }\end{array}$ \\
\hline \multicolumn{2}{|c|}{ Tipe } & & & \\
\hline \multirow{4}{*}{1} & KA & 30 & 0,884 & 30 & 1,660 \\
\cline { 2 - 6 } & KLA & 19 & 1,519 & 19 & 2,736 \\
\cline { 2 - 6 } & TT2 & 19 & 1,574 & 19 & 2,800 \\
\cline { 2 - 6 } & TT3 & 19 & 1,608 & 19 & 2,833 \\
\hline \multirow{4}{*}{2} & KA & 35 & 1,094 & 35 & 1,846 \\
\cline { 2 - 5 } & KLA & 29 & 1,533 & 29 & 2,357 \\
\cline { 2 - 5 } & TT2 & 29 & 1,584 & 29 & 2,392 \\
\cline { 2 - 5 } & TT3 & 29 & 1,601 & 29 & 2,499 \\
\hline \multirow{4}{*}{3} & KA & 28 & 1,002 & 28 & 1,644 \\
\cline { 2 - 5 } & KLA & 19 & 1,508 & 19 & 2,548 \\
\cline { 2 - 5 } & TT2 & 19 & 1,518 & 19 & 2,661 \\
\cline { 2 - 5 } & TT3 & 19 & 1,539 & 19 & 2,697 \\
\hline
\end{tabular}

Hubungan antara sudut kemiringan lereng dan model bentuk lereng terhadap nilai FK

\section{Lereng 1}

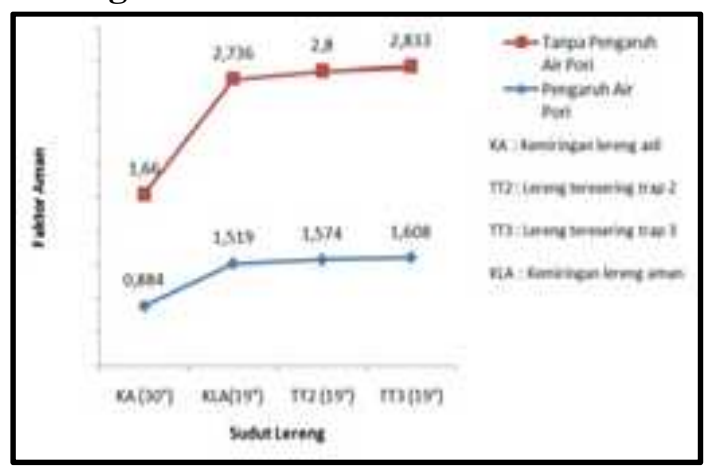

Gambar 4. Grafik hubungan FK dengan Sudut pada Lereng 1

\section{Lereng 2}

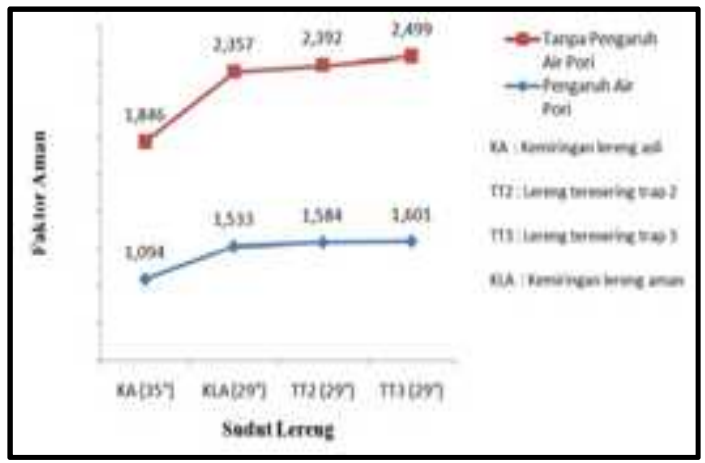

Gambar 5. Grafik hubungan FK dengan Sudut pada Lereng 2 


\section{Lereng 3}

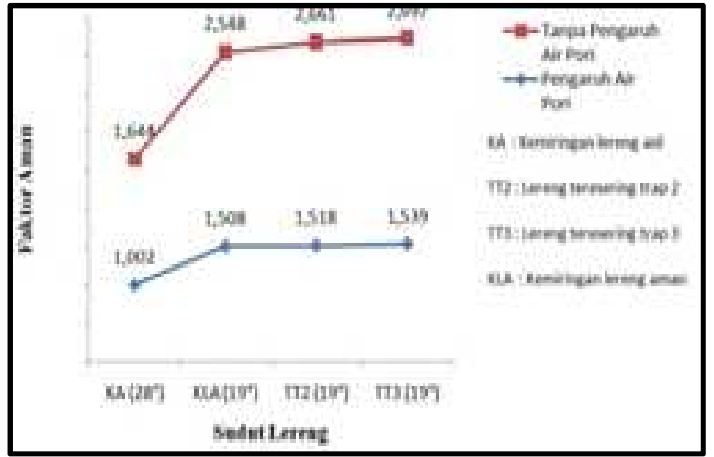

Gambar 6. Grafik hubungan FK dengan Sudut pada Lereng3

Berdasarkan grafik hubungan FK terhadap sudut kemiringan lereng dari variasi model bentuk lereng diketahui bahwa sudut kemiringan lereng dari variasi tipe lereng mempengaruhi nilai dari FK. Nilai sudut lereng yang besar dapat menyebabkan faktor aman (FK) lereng semakin kecil atau kritis. Dibuktikan pada ke tiga lereng, dari grafik nilai tersebut bahwa pada ketiga lereng mengalami kenaikan nilai FK dikarenakan sudut lereng semakin kecil. Variasi lereng juga mempengaruhi nilai FK pada lereng, dibuktikan dengan pada lereng yang memiliki kemiringan sudut sama namun berbeda bentuk variasi lereng memiliki nilai FK yang berbeda. Pada lereng terasering trap 3 memiliki nilai FK yang lebih besar dari pada model variasi lereng lain.

\section{KESIMPULAN}

Berdasarkan penelitian yang telah dilakukan meliputi uji sifat fisis tanah dan uji sifat mekanik tanah serta perhitungan analisis stabilitas lereng dengan menggunakan Metode Fellenius dibantu dengan program aplikasi Geostudio Slope/W 2012 dapat diambil beberapa kesimpulan:

1. Jenis tanah yang berada pada kawasan PLTA Musi Kepahiang adalah tanah lempung. Jenis tanah lempung dibuktikan dengan pengujian sifat fisis tanah melalui berat jenis tanah yang menunjukan bahwa tanah pada lereng 1 , lereng 2 dan lereng 3 memiliki nilai berat jenis antara 2,58-2,68 yang menunjukan jenis tanah adalah lempung. Pengujian nilai batas cair dan batas plastisitas juga menunjukan bahwa jenis tanah pada 3 lereng termasuk kedalam kelompok $\mathrm{OH}$ yang jenis tanah Lempung Organik.

2. Pengujian sifat mekanik tanah melalui Direct Shear Test mendapatkan hasil, pada lereng 1 didapat nilai $\phi^{\prime}=25,605^{\circ}$ dan $\mathrm{c}^{\prime}=21,758 \mathrm{Kpa}$, pada lereng 2 didapat nilai $\phi^{\prime}=25,602{ }^{\circ}$ dan $\mathrm{c}^{\prime}=24,881 \mathrm{Kpa}$, sedangkan pada lereng 3 didapat nilai $\phi^{\prime}=26,285^{\circ}$ dan $\mathrm{c}^{\prime}=24,774$ Kpa.

3. Perhitungan analisis stabilitas lereng menggunakan Geostudio Slope/W pada lereng yang dibuat terasering trap 3 memiliki niali FK yang lebih besar dari pada model variasi lereng lain. Lereng terasering trap 3 dengan mempertimbangkan pengaruh air pori pada lereng 1 dengan kemiringan sudut $19^{\circ}$ didapat $\mathrm{FK}=1,608>1,5$ (lereng aman). Lereng 2 dengan sudut kemiringan $29^{\circ}$ didapat $\mathrm{FK}=1,601>1,5$ (lereng aman). Lereng 3dengan sudut kemiringan $29^{\circ}$ didapat $\mathrm{FK}=1,539>1,5$ (lereng aman).

4. Perhitungan analisis stabilitas lereng menggunakan Geostudio Slope/W 2012, pada Lereng terasering trap 3 tanpa mempertimbangkan pengaruh air pori pada lereng 1 dengan kemiringan sudut $19^{\circ}$ didapat $\mathrm{FK}=2,833>1,5$ (lereng aman). Lereng 2 dengan sudut kemiringan $29^{\circ}$ didapat $\mathrm{FK}=2,499>1,5$ (lereng aman). Lereng 3dengan sudut kemiringan $29^{\circ}$ didapat $\mathrm{FK}=2,697>1,5$ (lereng aman).

5. Hubungan besar nilai sudut kemiringan lereng baik itu tanpa pengaruh air pori atau dengan pengaruh air pori terhadap nilai FK jika menggunakan parameter yang sama adalah semakin besar nilai sudut lereng maka nilai FK akan mengecil dan menjadi kritis serta model variasi lereng mempengaruhi nilai FK. 
6. Dari skenario 4 pemodelan lereng terdapat kelebihan diantaranya pada lereng yang di optimasi nilai FK akan lebih besar dengan pengurangan sudut kemiringan dan proses pengerjaan dilapangan lebih mudah dengan pemangkasan tinggi lereng, pada lereng terasering nilai FK lebih besar dari pada lereng asli namun, kelemahan pada pemodelan lereng ini adalah proses pengerjaan dilapangan yang sulit karena harus memangkas dan menimbun lereng untuk memperpanjang lereng sehingga sudut kemiringan berkurang.

\section{DAFTAR PUSTAKA}

Adi, M.W., 2018. Analisis Stabilitas Lereng dengan Program Komputer Geostudio 2012[skripsi]. Bengkulu (ID) Universitas Bengkulu

Das, B.M., 1994. Mekanika Tanah (Prinsip-Prinsip Rekayasa Geoteknis) Jilid 1. Mochtar NE, Mochtar IS, penerjemah. Jakarta (ID) : Erlangga.
Terjemahan dari : Principles of Geotechnical Engineering.

Das, B.M. 1994. Mekanika Tanah (Prinsip-Prinsip Rekayasa Geoteknis) Jilid 2. Mochtar NE, Mochtar IS, penerjemah. Jakarta (ID) : Erlangga. Terjemahan dari : Principles of Geotechnical Engineering.

Hardiyatmo, H. C., 2002. Teknik Pondasi 2, Edisi Kedua, Beta Offset, Yogyakarta.

Pohan, H.H., 2018. Analisis Stabilitas Lereng dengan Program Komputer Geostudio 2012[skripsi]. Bengkulu (ID) Universitas Bengkulu.

Suharyadi M.S., 1984. Geologi Teknik, Biro Penerbit KMTS FT UGM, Yogyakarta.

Terzaghi K., Peck R.B., 1987. Mekanika Tanah dalam Praktek Rekayasa Edisi Kedua Jilid 1. Witjaksono B, Krisna RB, penerjemah. Jakarta (ID) Erlangga.Terjemahan dari : Soil Mechanics. 